\title{
Accumulation of Copper, Lead, Chrome, Cadmium in Some Tissues of Procambarus clarkii in Rharb Region in Morocco
}

\author{
Ikram El Qoraychy1, Mohamed Fekhaoui², Abdellah El Abidi³, Rachid Benakame ${ }^{3}$, \\ Abdelkbir Bellaouchou', Ahmed Yahyaoui ${ }^{1}$ \\ ${ }^{1}$ Laboratory of Zoology and General Biology, Faculty of Science, Mohammed V University, Rabat, Morocco \\ ${ }^{2}$ Scientific Institute, Mohammed V University, Rabat, Morocco \\ ${ }^{3}$ National Institute of Hygiene, Rabat, Morocco \\ Email: Ikramelqoraychy@gmail.com
}

Received 11 September 2015; accepted 24 October 2015; published 27 October 2015

Copyright (C) 2015 by authors and Scientific Research Publishing Inc.

This work is licensed under the Creative Commons Attribution International License (CC BY).

http://creativecommons.org/licenses/by/4.0/

(c) (i) Open Access

\begin{abstract}
Different concentrations of four metals namely copper, lead, chrome and cadmium were evaluated in crayfish Procambarus clarkii tissues (carapace, flesh) for a six-month period, from March to August 2013 in the Rharb of Morocco (Lagoon Merja Zerga and Nador canal). The determination of heavy metals was carried using atomic absorption spectroscopy Varian VV20. The results obtained revealed a metal's contamination of Procambarus clarkii in both sites. Concentrations of heavy metals examined Procambarus clarkii carapace ranged as follows: Merja Zerga (Pb 2.07 - 6.7 $\mu \mathrm{g} / \mathrm{g}$; Cu 2.9 - $9.97 \mu \mathrm{g} / \mathrm{g}$; Cr 0.89 - 14.22 $\mu \mathrm{g} / \mathrm{g}$ dry weight) and Nador canal: (Pb 0.08 - $7.8 \mu \mathrm{g} / \mathrm{g}$; Cu $3.40-9.3 \mu \mathrm{g} / \mathrm{g} ; \mathrm{Cr} 0.87-3.5 \mu \mathrm{g} / \mathrm{g}$ dry weight). Concentrations of heavy metals found in flesh were as follows: Merja Zerga (Pb $0.02-5.25 \mu \mathrm{g} / \mathrm{g}$; Cu $9.58-23.59 \mu \mathrm{g} / \mathrm{g}$; $\mathrm{Cr} \mathrm{O}-2.71 \mu \mathrm{g} / \mathrm{g}$ dry weight) and Nador canal (Pb 0.06 - $6.81 \mu \mathrm{g} / \mathrm{g}$; Cu 9.5 - $37.20 \mu \mathrm{g} / \mathrm{g}$; $\mathrm{Cr} 0$ - $3.23 \mu \mathrm{g} / \mathrm{g}$ dry weight). The distribution of those metals in Procambarus clarkii shows high levels of contamination for lead, copper and chrome with an absence of cadmium in both sites (Merja Zerga and Nador canal). The concentrations differed in carapace and flesh.
\end{abstract}

\section{Keywords}

Procambarus clarkii, Heavy Metals, Merja Zerga, Nador Canal, Morocco

\section{Introduction}

Environmental pollution by heavy metals [1] is the element whose concentration in the environment is con-

How to cite this paper: El Qoraychy, I., Fekhaoui, M., El Abidi, A., Benakame, R., Bellaouchou, A. and Yahyaoui, A. (2015) Accumulation of Copper, Lead, Chrome, Cadmium in Some Tissues of Procambarus clarkii in Rharb Region in Morocco. Journal of Geoscience and Environment Protection, 3, 74-81. http://dx.doi.org/10.4236/gep.2015.38008 
stantly increasing [2]. Heavy metals of natural and anthropogenic sources are released into aquatic ecosystems, where they pose a serious threat because of their toxicity, long persistence, bioaccumulation and biomagnifications in the food chain [3]. Studies on heavy metals in rivers, lakes, fish and sediments have been a major environmental focus especially in the last decade. These elements, non-biodegradable [4] in aquatic environment can remain in solution or in suspension and precipitate on the bottom or be taken up by organisms. The analysis of metal concentrations in biota samples at the same locations can indicate the transfer of metals through food chains [5]. The use of biological indicator organisms to define areas of trace metal pollution appears most attractive, as these organisms not only concentrate metals in water, allowing inexpensive and relatively simple analysis, but they may also represent a moving time-averaged value for relative biological availability of metals at each sites studied [6]. Through analysis of metal concentrations in living organisms; crayfish Procambarus clarkii is the most cosmopolitan of crayfish species [7], it came from Louisiana (USA) and placed in the marshes of the River Guadalquivir near Sevilla (Spain) in 1974 [8]. Crayfish Procambarus clarkii is valuable materiel for the study of aquatic pollution in fresh water ecosystems, since it has been successfully established in various sites [9]. In aquatic ecosystems, the use of indicator species seems to be a suitable way of monitoring environmental quality due to the ability of some aquatic animals to accumulate metallic ions either directly from surrounding water or indirectly through food sources [10].

In Morocco, Merja Zerga waters are supplied by two regions, the Merja Rharb and the Loukkos. River Oued Drader supplies mostly Loukkos region while the larger area drained by the Nador canal is within the Rharb region [11].

Presence of heavy metals carried by the Oued Drader and Nador canal is noted especially during floods [12].

The present work aims to assess for the first time heavy metal concentrations in red swamp crayfish in these Moroccan ecosystems. Four heavy metals (cadmium, lead, chromium and copper) were selected for examination in carapace and flesh of Procambarus clarkii, as well as a comparison between the metal concentrations detected in the tissues in both study sites. Indeed the presence of these elements traces of specific toxicity constitutes not only a problem of the environment safeguarding but also a public health problem [13].

\section{Ease of Use}

\subsection{Sampling Sites of Study}

Procambarus clarkii has been successfully established in various sites of the lagoon Moulay Bousselham in Rharb region West of Morocco. The first observation of the species in late 2008 early 2009 in Merja zerga; coincides with the introduction, in 2007, by the Spanish company ALFOCAN (company for processing and marketing wild-caught freshwater crayfish). The current distribution of $P$. clarkii in Morocco has been identified at swamps and rice fields of larache, the region of Rharb between Merja Zerga and Souk Larbaa at north dar Gueddari and Allal Tazi in the south west of Atlantic Ocean (lake, irrigation and drainage canals, temporary merjas and rice fields).

Procambarus clarkii were collected from Merja Zerga and Nador canal.

Merja Zerga $34^{\circ} 86^{\prime} \mathrm{N} / 06^{\circ} 28^{\prime} \mathrm{W}$ a permanent biological reserve, Ramsar site (1980) is a tidal lagoon located $70 \mathrm{~km}$ north of Kenitra on the Atlantic coast [14], the lagoon water system is mainly supplied by the Drader River to the east and the Nador canal to the south [11], its linked to the Atlantic Ocean by a single channel (the "gullet"), that is strongly tidal and at high tide, is connected with a smaller lagoon, the Merja Kahla [15]. Merja Zerga is well known as a bird reserve and as an area of outstanding natural beauty. Its hydrology and Vegetation have been studied since the 1970s and the plankton since 1986 [16]-[18].

The Nador canal was built in 1953; its mean annual discharge has been estimated at $150 \times 10^{6} \mathrm{~m}^{3} /$ year the canal drains flooded depressions (agricultural areas) of the Rharb costal [19].

\subsection{Sampling and Analysis}

Red crayfish Procambarus clarkii samples were collected monthly from March to August 2013. The 500 grams flesh and carapace crayfish samples obtained after dissection were placed in an incubator at $65^{\circ} \mathrm{C}$ for $48 \mathrm{~h}$ until complete drying and then ground using porcelain mortar. For this purpose, fractions of $0.5 \mathrm{~g}$ of the dried samples are prepared for measurement concentrations. They were placed in clean digestion bombs, to P. clarkii flesh was added $4 \mathrm{ml}$ of nitric acid $65 \% \mathrm{HNO}_{3}$, to the carapace samples were added $4 \mathrm{ml}$ of water and $4 \mathrm{ml}$ of regal hydrofluoric acid in the presence of boric acid (Suprapur quality, Merck). The Samples were kept overnight for 
predigesting, the next day they were placed in sand bath at $120^{\circ} \mathrm{C}$ for $4 \mathrm{~h}$ until the solution became clear. After cooling, the samples were transferred into dilution tubes of $50 \mathrm{ml}$, filled up with $30 \mathrm{ml}$ samples and the rest with distilled water, [20]. Assays metals were performed on digests diluted [20]-[22]. Cd, Cr, Cu and Pb were Determined by atomic absorption spectrophotometer graphite furnace (Varian AA 20).The validity of the Analytical methods was checked internal control by using standard samples (National research council of Canada) Bess-1 for the shells and DROM-2 for crustaceans and external control by inter calibration exercises (AIEA-MESL2014-01-TE).

\subsection{Statistical Analysis}

Statistical differences between the different tissues (carapace and flesh) were determined with Excel.

\section{Results and Discussion}

The metal concentrations analyzed in crayfish Procambarus clarkii sampled from two sites (Figure 1 and Figure 2) summarize mean concentrations of studied metals traces.

\subsection{Cadmium}

Cadmium is generally a non-essential element with teratogenic, carcinogenic, and highly nephrotoxic effects on living organisms [23] [24] and by extension to the consumers [25].

Our results present the contamination of cadmium in Procambarus clarkii in both sites of Merja Zerga and Nador canal (0.0009 and $0.0002 \mu \mathrm{g} / \mathrm{g}$ dry weight) in carapace and in flesh $(0.006$ and $0.01 \mu \mathrm{g} / \mathrm{g}$ dry weight) (Figure 1 and Figure 2). In absence of national regulatory standards for normal levels of traces elements and according to Spanish legislation, a maximum limit for heavy metal in edible wet mass of $\mathrm{Cd}$ is $\mathrm{Cd}$ is $1 \mu \mathrm{g} / \mathrm{g}$

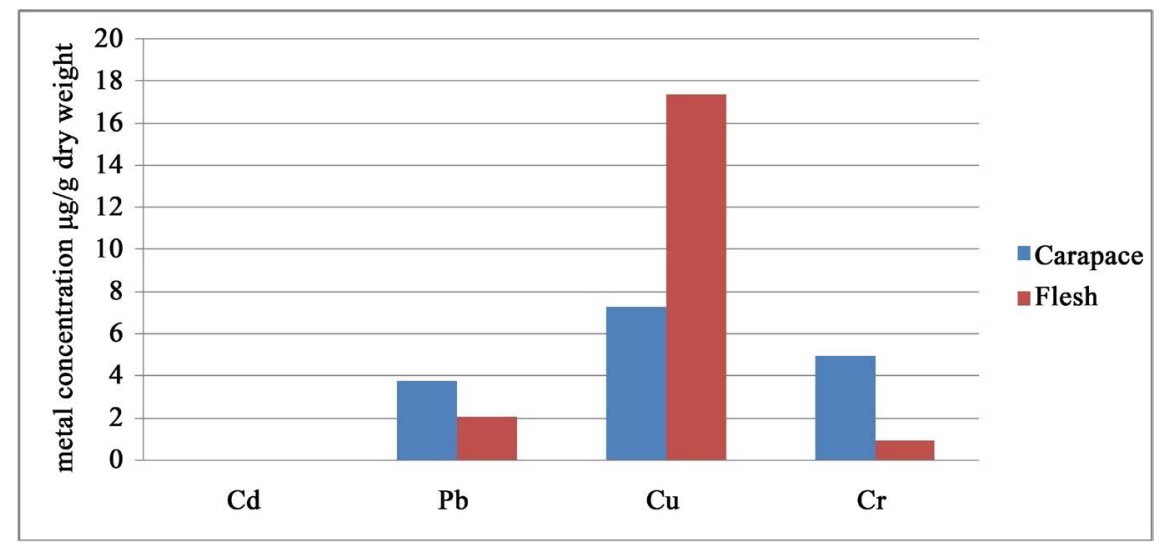

Figure 1. Distribution of $\mathrm{Cd}, \mathrm{Pb}, \mathrm{Cu}$, and $\mathrm{Cr}$ in carapace and flesh of Procambarus clarkia (Merja Zerga).

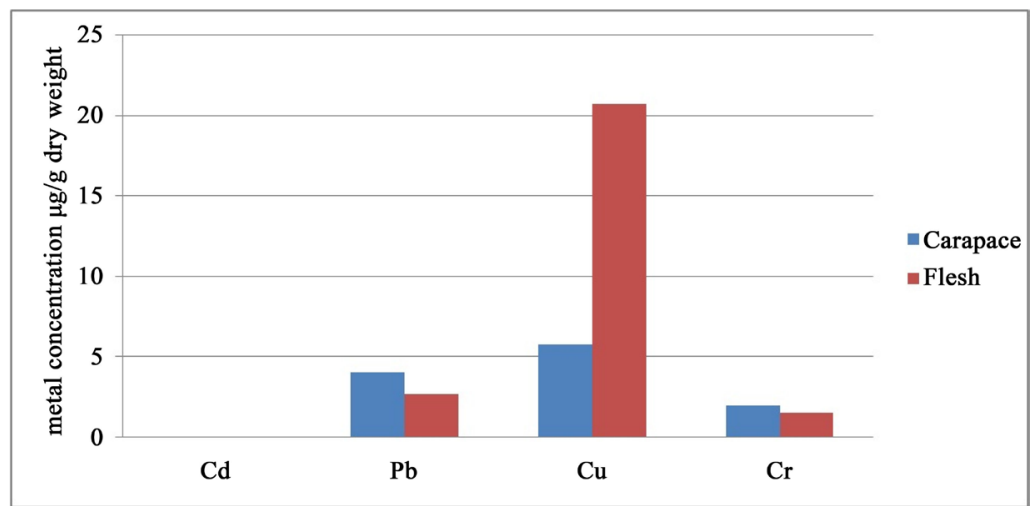

Figure 2. Distribution of $\mathrm{Cd}, \mathrm{Pb}, \mathrm{Cu}$ and $\mathrm{Cr}$ in carapace and flesh of Procambarus clarkii (Nador canal). 
(BOE 195, 15/8/1991) whereas European legislation limit is of $0.8 \mu \mathrm{g} / \mathrm{g}$ (EC Regulation 466/2001) [26].

We can say that concentrations are very low and indicate that both sites are non-polluted by cadmium (Figures 3-6); accumulation of environmental cadmium in crayfish tissues has been reported. Levels of environmental pollution have shown positive correlations with concentrations in tissue samples [1].The highest concentrations of cadmium in Procambarus clarkii were found in hepatopancreas, alimentary tract, and in a less extent in blood and exoskeleton. The least affected tissues were abdominal muscles [27]. Cadmium levels in abdominal muscles and hepatopancreas in Procambarus clarkii were in Spain from an unpolluted locality ( $0.02 \mu \mathrm{g} / \mathrm{g}$ dry weight) in abdominal muscles [28], in USA from an unpolluted locality $(0.73-0.33 \mu \mathrm{g} / \mathrm{g})$ in abdominal muscles and $(0.30$ $0.26 \mu \mathrm{g} / \mathrm{g}$ dry weight) in hepatopancreas [29] And (0.0005 $\mu \mathrm{g} / \mathrm{g}$ dry weight) in abdominal muscles [30] and (0.1 $\mu \mathrm{g} / \mathrm{g}$ dry weight) in hepatopancreas [30] and (0.03 $\mu \mathrm{g} / \mathrm{g}$ dry weight) in abdominal muscles [30], in Egypt (1.97 $\mu \mathrm{g} / \mathrm{g}$ wet weight) in abdominal muscles [31].

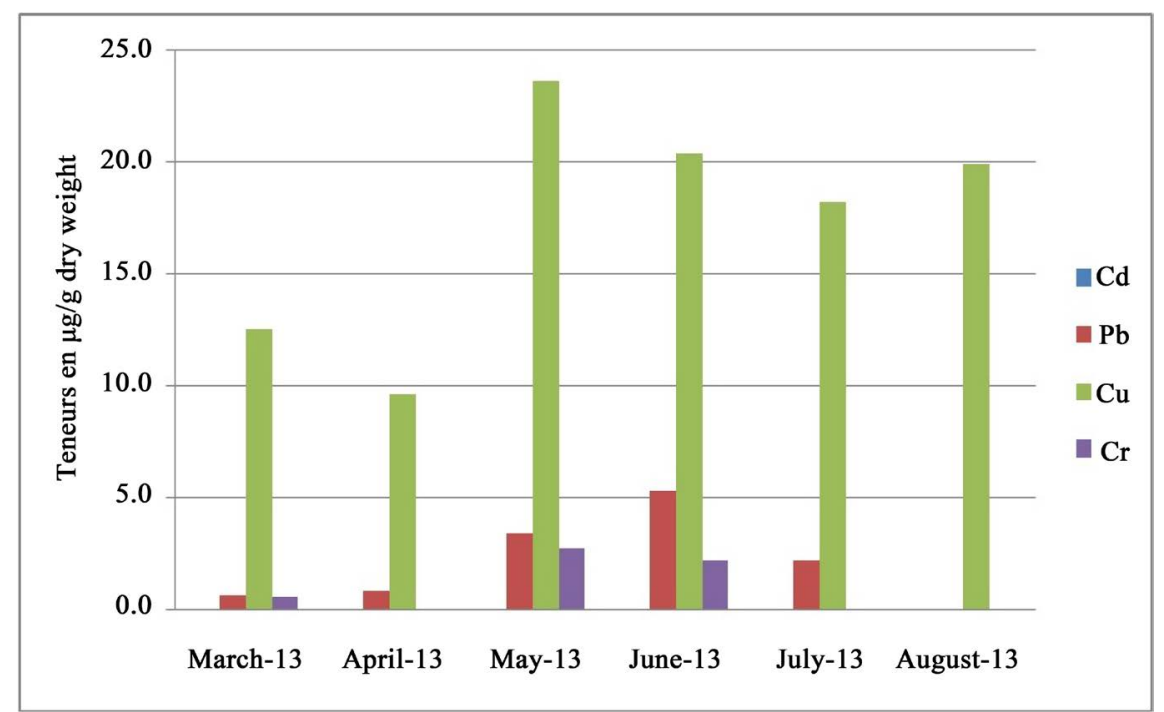

Figure 3. Distribution of $\mathrm{Cd}, \mathrm{Pb}, \mathrm{Cu}$ and $\mathrm{Cr}$ in flesh from March to August of Procambarus clarkii (Merja Zerga).

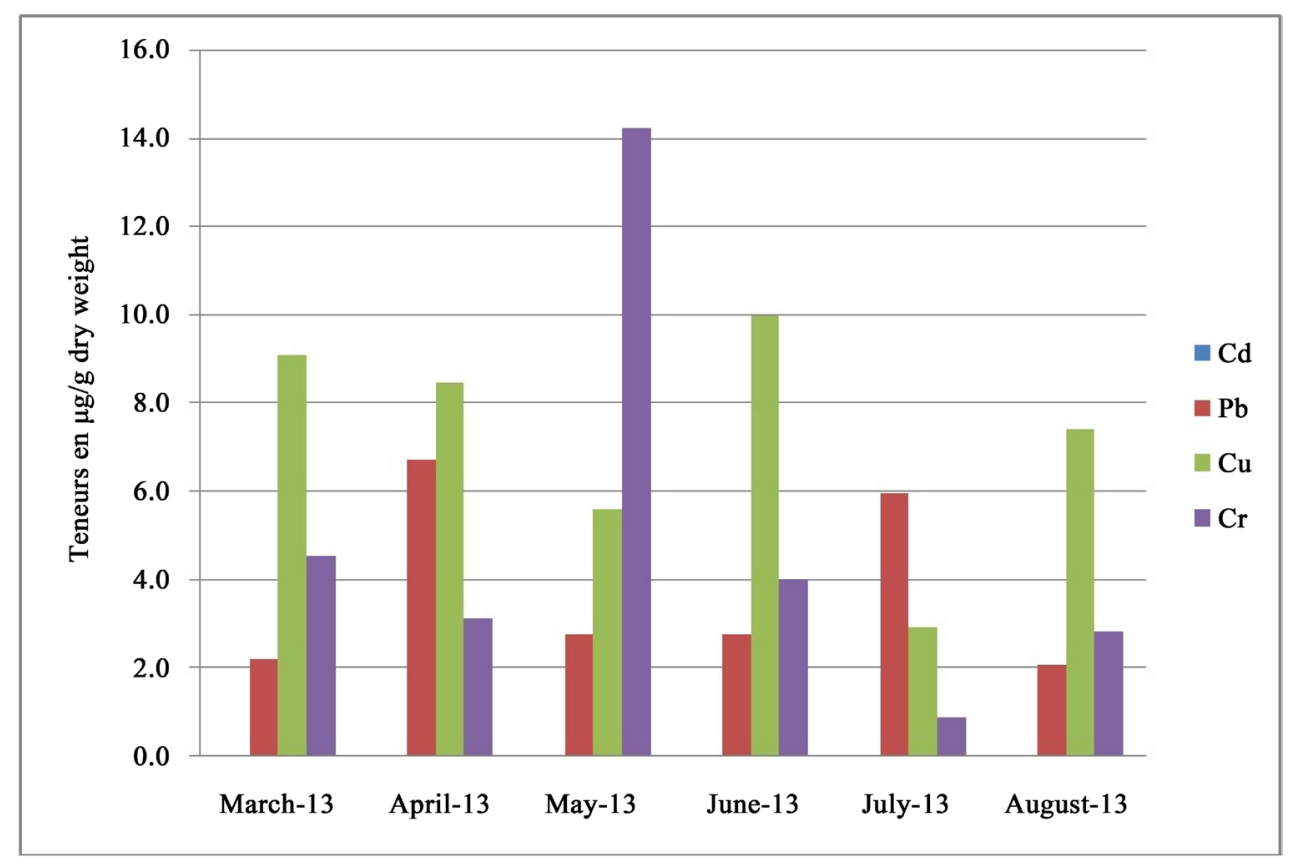

Figure 4. Distribution of $\mathrm{Cd}, \mathrm{Pb}, \mathrm{Cu}$ and $\mathrm{Cr}$ in carapace from March to August of Procambarus clarkii (Merja Zerga). 


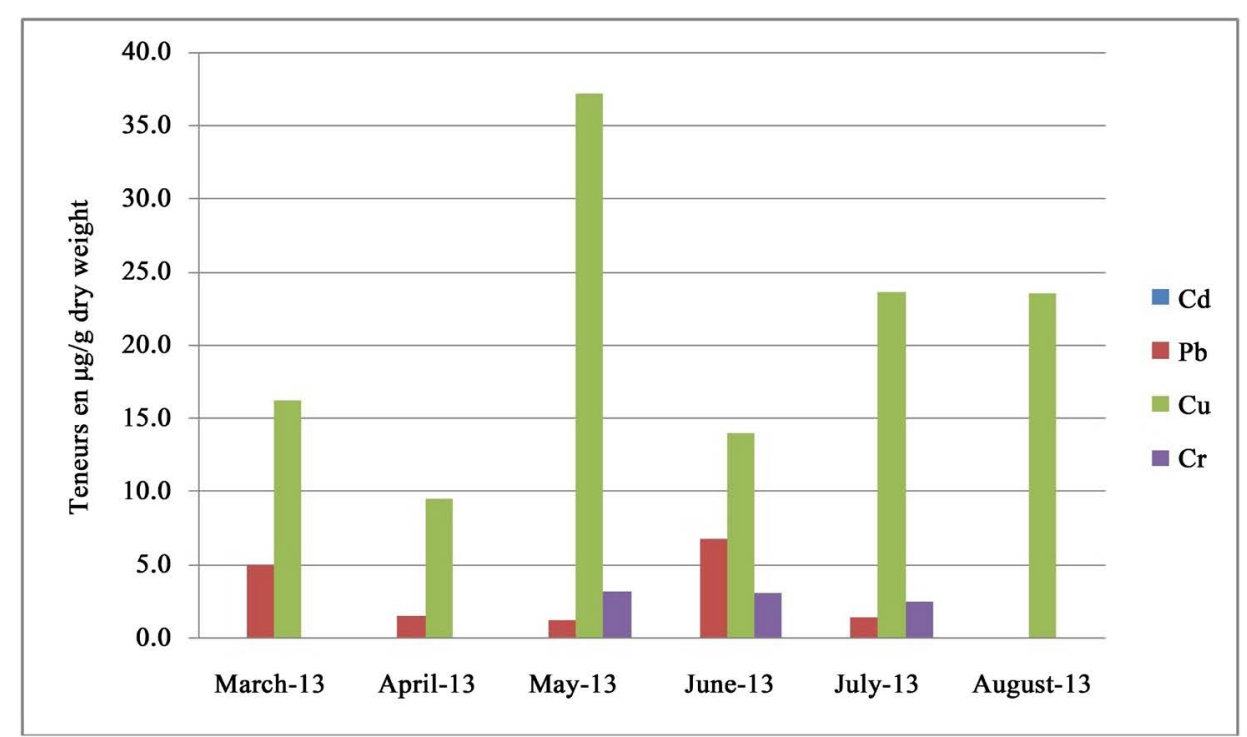

Figure 5. Distribution of $\mathrm{Cd}, \mathrm{Pb}, \mathrm{Cu}$ and $\mathrm{Cr}$ in flesh from March to August of Procambarus clarkii (Nador canal).

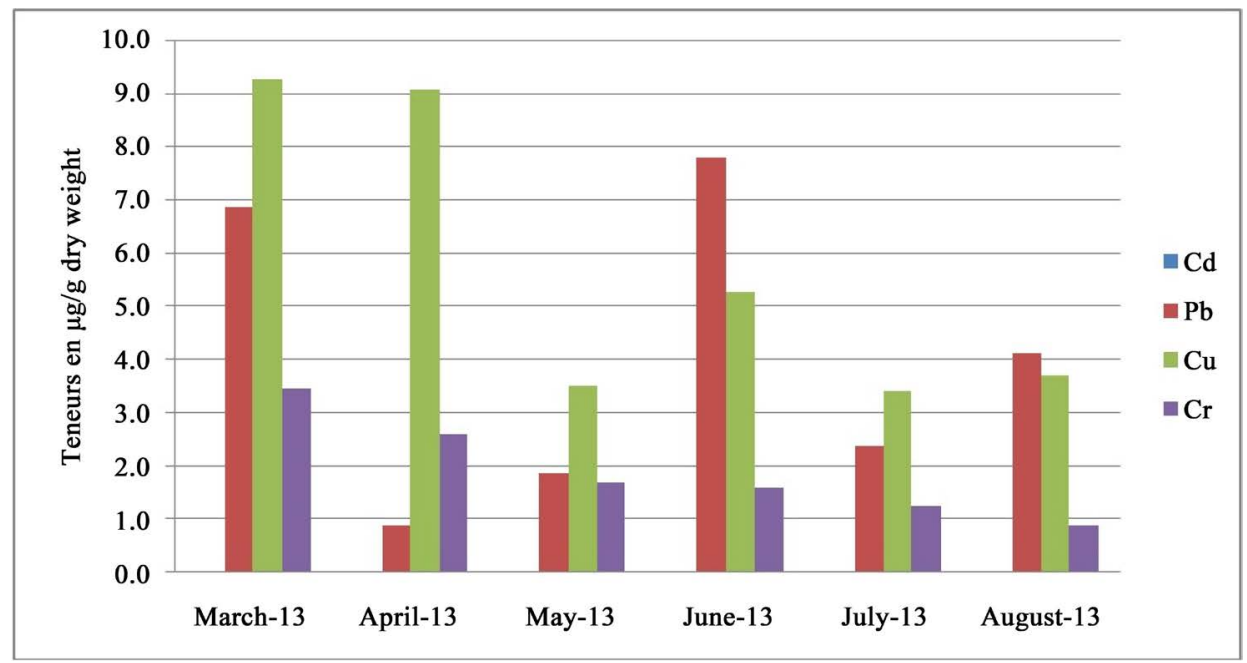

Figure 6. Distribution of $\mathrm{Cd}, \mathrm{Pb}, \mathrm{Cu}$ and $\mathrm{Cr}$ in carapace from March to August of Procambarus clarkii (Nador canal).

\subsection{Lead}

Lead is an element which is much used in modern industry [2], is probably a result of metal introduced into the environment via emissions from agricultural machinery and automobiles [27].

Even though no significant differences in lead concentrations between the two sites, high concentrations of lead in both sites especially in carapace was observed (Figures 3-6). Lead accumulated was mainly detected in

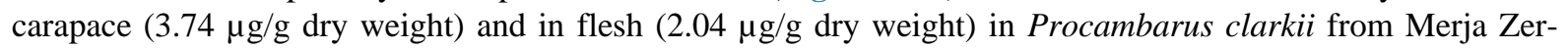
ga .Those caught from the Nador canal contained $3.98 \mu \mathrm{g} / \mathrm{g}$ dry weight of lead in carapace and $2.67 \mu \mathrm{g} / \mathrm{g}$ dry weight in flesh (Figure 1 and Figure 2). According to Spanish legislation, a maximum limit for heavy metal in edible wet mass of $\mathrm{Pb}$ is of $1 \mu \mathrm{g} / \mathrm{g}$ (BOE 195, 15/8/1991), whereas European legislation limits is of $0.8 \mu \mathrm{g} / \mathrm{g}$ (EC Regulation 466/2001) [26]. Our results show that lead non essential element accumulates in Procambarus clarkii caught from Merja Zerga and Nador canal due to the several paddy field (culture of rice) Rotation of rice and crawfish takes advantage of the seasonality of each crop which allows for the production and harvest of each crop in one year. Rice is grown and harvested in the summer months while crawfish grown during the fall, winter and spring in the same field in a twelve month period [32] (Figures 3-6). The concentration of Pb in Procambarus Clarkii varied between 3.74 and $3.98 \mu \mathrm{g} / \mathrm{g}$ dry weights in carapace and $2.04-2.67 \mu \mathrm{g} / \mathrm{g}$ dry weight in 
flesh (Figure 1 and Figure 2). The metal was accumulated primarily in the hepatopancreas, carapace, and gills and reached only low concentrations in the hindgut and muscle [1]. Mean lead concentrations in abdominal muscle and hepatopancreas of crayfish expressed as $\mathrm{mg} / \mathrm{kg}$ dry tissue weight respectively were in USA ( $<5.0$ $\mathrm{mg} / \mathrm{kg},<5.0 \mathrm{mg} / \mathrm{kg}$ ) [29], (0.06 and $0.04 \mathrm{mg} / \mathrm{kg}$ ) from an unpolluted locality, (<0.19 mg/kg wet weight) in abdominal Muscle [30] and in Egypt (15.93 mg/kg wet weight) in abdominal muscle [31].

\subsection{Copper}

Copper is essential micronutrient, do not accumulate in decapods crustaceans up to certain threshold levels [33]. It is a component of respiratory mettalloprotein-hemocyanin in crustaceans [34] [35]. Copper (Cu) remains among the essential trace elements and indispensable for the proper functioning of the body [36]. In our study, copper detected in Merja Zerga and Nador canal showed high levels in flesh and carapace (Figures 3-6). Copper concentration in flesh was considerably lower than it is in carapace. The copper concentrations in carapace were higher in Merja Zerga than in Nador canal: levels detected are respectively $7.24 \mu \mathrm{g} / \mathrm{g}$ dry weight and $5.70 \mu \mathrm{g} / \mathrm{g}$ dry weight. In flesh, copper concentrations in Merja Zerga are lower than in Nador canal $(17.33 \mu \mathrm{g} / \mathrm{g}, 20.69$ $\mu \mathrm{g} / \mathrm{g}$ dry weight) (Figure 1 and Figure 2). The activities identified in the drainage areas particularly the use of copper sulfate in rice agriculture may explain this [1]-[3] (Figures 3-6). Cu was higher than world average at every station along the Merja Zerga [37]. According to Spanish legislation, a maximum limit for heavy metal in edible wet mass of $\mathrm{Cu}$ is $20 \mu \mathrm{g} / \mathrm{g}$ (BOE 195, 15/8/1991) [26]. Accumulation of copper was observed in tissues in the following decreasing order: gills $>$ exoskeleton $>$ abdominal muscle [1].

Mean lead concentrations in abdominal muscle and hepatopancreas of crayfish expressed as mg/kg dry tissue weight were in USA 5.9 - $5.3 \mathrm{mg} / \mathrm{kg}$ wet weight [29], respectively $76.908 \mathrm{mg} / \mathrm{kg}$ dry weight [30], in abdominal muscle 34.7 and $25.1 \mathrm{mg} / \mathrm{kg}$ wet weight [29], $506 \mathrm{mg} / \mathrm{kg}$ in hepatopancreas [38], and in Egypt $125.8 \mathrm{mg} / \mathrm{kg} \mathrm{dry}$ weight in abdominal muscle [31]. Crayfish has a great potential for rapid accumulation and depuration of Cu in fresh waters. If these animals from a contaminated area are consumed in large quantities they could cause adverse health consequences [26].

\subsection{Chromium}

Chromium is an essential trace element for humans and animals, used in industry to make stainless steel alloys which improves many properties, and used as a catalyst as well as for tanning and impregnation of wood. It in air chromium originates from industrial emissions [2]. Chromium accumulation in carapace was greater than flesh in both sites (Figures 3-6). Furthermore, chromium levels in Merja Zerga were higher than Nador canal for

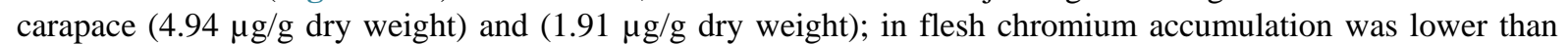
carapace. Chromium levels in Merja Zerga were lower than Nador canal for flesh $0.92 \mu \mathrm{g} / \mathrm{g}$ dry weight and 1.47 $\mu \mathrm{g} / \mathrm{g}$ dry weight (Figure 1 and Figure 2). In USA level concentrations of $\mathrm{Cr}$ in abdominal muscle is of 0.43 $\mathrm{mg} / \mathrm{kg}$ dry weight [30], and in Egypt is of $5.03 \mathrm{mg} / \mathrm{kg}$ wet weight [31].

\section{Conclusions}

1) This study revealed high concentrations of heavy metals $\mathrm{Pb}, \mathrm{Cu}$ and $\mathrm{Cr}$ in Procambarus clarkii in both carapace and flesh from Merja Zerga and Nador canal, and detected the absence of cadmium in both sites.

2) Thus, crawfish could be used as bioindicator of these pollutants since their dose and time-dependent accumulation might be reflective of concentrations of nonessential metals in polluted wetlands and could indicate the toxicological risk which could be induced by its consumption.

3) The region of Gharb has a great ecological, economical and halieutic value. This study revealed that Procambarus clarkii is of a great importance since these aquatic organisms are considered as effective bioindicator of pollution.

4) Procambarus clarkii as a sentinel species to monitor environmental health is also justified by its ability to bind and accumulate different toxic minerals and it can be a very useful tool for estimating the level of pollution in the hydrological system.

\section{Acknowledgements}

This work was done in the National Institute of Hygiene, Rabat, in the Laboratory of Zoology and General Bi- 
ology, Faculty of science, Rabat and in Scientific Institute, Mohammed V University, and Rabat. We want to thank laboratory of toxicology in National institute of Hygiene for his technical assistance.

\section{References}

[1] Antonín, K., Miloš, B. and Pavel, K., (2010) Bioaccumulation and Effects of Heavy Metals in Crayfish: Review. Water Air Soil Pollution, 211, 5-16. http://dx.doi.org/10.1007/s11270-009-0273-8

[2] Branko, A., Snezana, D., Danijela, S., Dejan, J. and Sladjana, K. (2015) Comparative Analysis of Trace Elements in the Mosses-Bryum argenteum Hedw. and Hypnum cupressiforme Hedw. in Podgorica (Montenegro). Journal of Materials and Environmental Science, 6, 333-342.

[3] Kucykbay, F.Z. and Orun I. (2003) Copper and Zinc Accumulation in Tissues of the Freshwater Fish Cyprinus carpio Collected from the Karakaya Dam Lake, Malatya (Turkey). Fresenius Environmental Bulletin, 12, 62-66.

[4] Ouihman, E., Hbaiz, E., Lebkiri, M., Lebkiri, A., Rifi, E. and Ouzair, A. (2012) Bioaccumulation of the Metal Elements Traces by the Radish (Raphanus sativus) Cultivated on Grounds Amended by Muds of a Sewage Treatment Plant. Journal of Materials and Environmental Science, 3, 469-476.

[5] Topcuoglu, S., Kırbasßoglu, C. and Gungor, N. (2002) Heavy Metals in Organisms and Sediments from Turkish Coast of the Black Sea. Environmental International, 1069, 1-8.

[6] David, J. and Philips, H. (1977) The Use of Biological Indicator Organisms to Monitor Trace Metal Pollution in Marine and Estuarine Environments-A Review. Environmental Pollution, 13, 281-317.

[7] Huner, J.V. and Barr, J.E. (1984) Red Swamp Crawfish: Biology and Exploitation Baton Rouge. LA: Louisiana Sea Grant College Program, Center for Wetland Resources, Louisiana State University.

[8] Habsburgo-Lorena, A.S. (1978) Present Situation of Exotic Species of Crayfish Introduced into Spanish Continental Waters. In: Laurent, P.J., Ed., Freshwater Crayfish, Institut National de la Recherche Agronomique, Thonon-les-Bains, 175-184.

[9] Khadiga, M.S., Fadia, N.H. and Naglaa, M.G. (2001) Accumulation of Copper, Lead and Cadmiumin Some Tissues of the Crayfish Procambarus clarkii (Cambaridae, Crustacea). Egyptian Journal of Aquatic Biology and Fisheries, 2, 47-56.

[10] Devi, M., Thomas, D.A., Barber, J.T. and Fingerman, M. (1996) Accumulation and Physiological and Biochemical Effects of Cadmium in a Simple Aquatic Food Chain. Ecotoxicology and Environmental Safety, 33, 38-43. http://dx.doi.org/10.1006/eesa.1996.0004

[11] Ayache, F., Thompson, J.R., Flower, R.J., Boujarra, A., Rouatbi, F. and Makina, H. (2009) Environmental Characteristics, Landscape History and Pressures on Three Coastal Lagoons in the Southern Mediterranean Region: Merja Zerga (Morocco), Ghar El Melh (Tunisia) and Lake Manzala (Egypt). Hydrobiologia, 622, 15-43.

[12] Mergaoui, R.L. (2005) Diagnostic d'un état de pollution organique et métallique de deux zones humides: Cas de Merja Zerga et de Sebou. Thèse 3ème cycle, Université Mohamed V, Faculté des sciences, Rabat, 152.

[13] El Morhit, M., Fekhaoui, M., El Abidi, A. and Yahyaoui, A. (2012) Impact des activités humaines sur la dégradation de la qualité des sédiments de l'estuaire de Loukkos (Maroc). Déchets, Sciences et Techniques, No. 61, 1-21. http://dx.doi.org/10.4267/dechets-sciences-techniques.2607

[14] Wariaghli, F., Tigilliman, A., El Abidi, A., El Hamri, H., Fekhaoui, M. and Yahyaoui, A. (2013) Anguilla anguilla L: Evaluation of the Degree of Heavy Metal Contamination in the Sebou Estuary and in Moulay Bousselham Lagoon Reserve (Morocco). International Journal of Aquatic Science, 2, 69-82.

[15] Ramdani, M., Elkhiati, N., Flower, R.J., Thompson, J.R., Chouba, L., Kraiem, M.M., Ayache, F. and Ahmed, M.H. (2009) Environmental Influences on the Qualitative and Quantitative Composition of Phytoplankton and Zooplankton in North African Coastal Lagoons. Hydrobiologia, 622, 113-131. http://dx.doi.org/10.1007/s10750-008-9678-4

[16] Ramdani, M. (1988) Les eaux stagnantes du Maroc: Etudes biotypologique et biogéographique du zooplancton. Travaux Institut Scientifique Rabat, Serie Zoologie, 43, 1-40.

[17] Ramdani, M., Elkhiati, N., Flower, R.J., Kraiem, M.M., Fathi, A.A., Birks, H.H. and Patrick, S.T. (2001) Open Water Zooplankton Communities in North African Wetland Lakes: The CASSARINA Project. Aquatic Ecology, 35, 319-333. http://dx.doi.org/10.1023/A:1011926310469

[18] Fraikech, M., Berraho, A., Ramdani, M., Chafik, A., Serghini, M. and Moukrim, A. (2005) Evolution spatio-temporelle des dinoflagellés dans la baie d'Agadir Maroc. Marine Life, 15, 19-27.

[19] Snoussi, M. and Ouknine, L. (2006) Water, Salt and Nutrient Budgets for Moulay Bousselham Lagoon, Morocco. LOICZ-Biogeochemical Modelling Node.

[20] Auger, D. (1989) Méthode de dosage du plomb, du cadmium, du cuivre et du zinc dans les milieux biologiques. 
Direction de l'environnement et de recherché océaniques.

[21] Bouachrine, M., Fekhaoui, M., Bennasser, L. and Idrissi, L. (1998) Distribution of Selected Metals in Tissue Samples of Fish from Industrially Contaminated Stream (The River Sebou, Morocco). Acta Hydrobiol, 40, 173-179.

[22] Chiffoleau, J.F. and Truquet, I. (1994) Nouvelles méthodes de dosage de quelques métaux traces dans les sédiments et les matières en suspension. Ifremer, 8-94.

[23] Eisler, R. (1997) Copper Hazards to Fish, Wildlife, and Invertebrates: A Synoptic Review. Biological Science Report USGS/BRD/BSR-1997-0002.

[24] Anderson, R.V., Vinikour, W.S. and Brower, J.E. (1978) The Distribution of Cd, Cu, Pb and Zn in the Biota of Two Freshwater Sites with Different Trace Metal Inputs. Ecography, 1, 377-384. http://dx.doi.org/10.1111/j.1600-0587.1978.tb00973.x

[25] Sbihi, K., Cherifi, O., El gharmali, A., Oudra, B. and Aziz, F. (2012) Accumulation and Toxicological Effects of Cadmium, Copper and Zinc on the Growth and Photosynthesis of the Freshwater Diatom Planothidium lanceolatum (Brébisson) Lange-Bertalot: A Laboratory Study. Journal of Materials and Environmental Science, 3, 497-506.

[26] Naqvi, S.M., Devalraju, I. and Naqvi, N.H. (1998) Copper Bioaccumulation and Depuration by Red Swamp Tray Fish Procambarus clarkii. Bulletin of Environmental Contamination and Toxicology, 61, 65-71. http://dx.doi.org/10.1007/s001289900730

[27] Madigosky, S.R., Alvarez-Hernandez, X. and Glass, J. (1991) Lead, Cadmium, and Aluminum Accumulation in the Red Swamp Crayfish Procambarus clarkii G. Collected from Roadside Drainage Ditches in Louisiana. Archives of Environmental Contamination and Toxicology, 20, 253-258. http://dx.doi.org/10.1007/BF01055912

[28] Díaz-Mayans, J., Hernández, F., Medina, J., Del Ramo, J. and Torreblanca, A. (1986) Cadmium Accumulation in the Crayfish, Procambarus clarkii, Using Graphite Furnace Atomic Absorption Spectroscopy. Bulletin of Environmental Contamination and Toxicology, 37, 722-729. http://dx.doi.org/10.1007/BF01607831

[29] Madden, J.D., Grodner, R.M., Feagley, S.E., Finerty, M.W. and Andrews, L.S. (1991) Minerals and Xenobiotic Residues in the Edible Tissues of Wild and Pond-Raised Louisiana Crayfish. Journal of Food Safety, 12, 1-15. http://dx.doi.org/10.1111/j.1745-4565.1991.tb00062.x

[30] Hothem, R.L., Bergen, D.R., Bauer, M.L., Crayon, J.J. and Meckstroth, A.M. (2007) Mercury and Trace Elements in Crayfish from Northern California. Bulletin of Environmental Contamination and Toxicology, 79, 628-632.

[31] Abd-Allah, M.A. and Abdullah, M.A. (1966) Effect of Cooking on Metal Content of Freshwater Crayfish. Procambarus clarkii. Oikos, 17, 96-107.

[32] Sneddon, J. and Richert, J.C. (2011) Metals in Crawfish. In: Sladonja, B., Ed., Aquaculture and the Environment-A Shared Destiny, InTech, Rijeka, 195-215. http://dx.doi.org/10.5772/28861

[33] Alcorlo, P.M., Otero, M., Crehuet, M., Baltanás, A. and Montes, C. (2006) The Use of the Red Swamp Crayfish (Procambarus clarkii, Girard) as Indicator of the Bioavailability of Heavy Metals in Environmental Monitoring in the River Guadiamar (SW, Spain). Science of the Total Environment, 366, 380-390. http://dx.doi.org/10.1016/j.scitotenv.2006.02.023

[34] Rainbow, P.S. (2002) Trace Metal Concentrations in Aquatic Invertebrates: Why and So What? Environmental Pollution, 120, 497-507. http://dx.doi.org/10.1016/S0269-7491(02)00238-5

[35] White, S.L. and Rainbow, P.S. (1982) Regulation and Accumulation of Copper, Zinc and Cadmium by the Shrimp Palaemon elegans. Ecology Progress Series, 8, 95-101. http://dx.doi.org/10.3354/meps008095

[36] Chafik, A., Eddoha, R., Bagrin, A., Nasser, B. and Essamadi, A. (2014) Copper and Zinc Contents in Different Organs of Animals Slaughtered in Casablanca City-Morocco. Journal of Materials and Environmental Science, 5, 1737-1741.

[37] Alaoui, A.M., Choura, M., Maanan, B.Z., Marc, R., Freitas, M.C., Cesar, A., Mehdi, K. and Christian, C. (2010) Metal Fluxes to the Sediments of the Moulay Bousselham Lagoon, Morocco. Environmental Earth Sciences, 61, 275-286. http://dx.doi.org/10.1007/s12665-009-0341-9

[38] Gherardi, F., Barbaresi, S., Vaselli, O. and Bencini, A. (2002) A Comparison of Trace Metal Accumulation in Indigenous and Alien Freshwater Macro-Decapods. Marine and Freshwater Behaviour and Physiology, 35, 179-188. http://dx.doi.org/10.1080/1023624021000014761 